\title{
PENGEMBANGAN MEDIA KOMIK TEMATIK ISLAMI
}

\author{
Nurul Fadillah, Nirwana Anas, Rora Rizky Wandini \\ Surel: nurulfadillah037@gmail.com
}

\begin{abstract}
This study aims to develop Islamic Thematic Comics as a valid, practical and effective learning media. The methods used in this study were validation sheets, questionnaires and learning outcomes tests. The type of this research is $R \& R$ research with Borg and Gall research design. The results showed that the Islamic Thematic Comic product based on the value given by the valid validator obtained a value of $94.01 \%$ in the "Very Eligible" category, the practicality level obtained a value of $77.60 \%$ in the "Very Eligible" category and was declared effective with an increase in the value of 76.00 and after using Comics, which is 81.67. Based on the results of the tests carried out, it can be concluded that the development of Islamic Thematic Comics products to improve student learning outcomes is declared valid, practical, and effective.
\end{abstract}

Keywords: Islamic, Thematic, Comic Media.

\begin{abstract}
ABSTRAK
Penelitian ini bertujuan untuk mengembangkan Komik Tematik Islami sebagai media pembelajaran yang valid, praktis dan efektif. Metode yang digunakan dalam penelitian ini adalah lembar validasi, angket dan tes hasil belajar. Jenis penelitian ini yaitu penelitian $\mathrm{R} \&$ dengan desain penelitian Borg and Gall. Hasil penelitian menunjukkan bahwa produk Komik Tematik Islami berdasarkan nilai yang diberikan oleh validator valid memperoleh nilai $94.01 \%$ dengan kategori "Sangat Layak", tingkat kepraktisan memperoleh nilai $77.60 \%$ dengan kategori "Sangat Layak" dan dinyatakan efektif dengan peningkatan nilai 76.00 dan sesudah menggunakan Komik, yaitu 81.67. Berdasarkan hasil uji yang dilakukan dapat disimpulkan bahwa pengembangan produk Komik Tematik Islami untuk meningkatkan hasil belajar siswa dinyatakan valid, praktis, dan efektif.
\end{abstract}

Kata Kunci: Islami, Tematik, Media Komik.

\section{PENDAHULUAN}

Media pembelajaran adalah segala sesuatu yang dapat digunakan untuk menyalurkan pesan dari pengirim ke penerima pesan (Sadiman, 2008), semua alat (bantu) atau benda yang digunakan untuk kegiatan pembelajaran, dengan tujuan penyampaian pesan (informasi) dalam ini materi pembelajaran dari sumber (guru atau kurikulum) ke pada penerima (peserta didik atau yang menjadi sasaran pembelajaran (Latuheru, 1988), dan teknologi yang tidak hanya sekedar menyampaikan konten tetapi memainkan peran pedagogis (Koehler dkk, 2005). Merujuk kepada definisi yang dikutip terkait definisi media pembelajaran sebagai segala sesuatu yang dapat menyampaikan pesan, dapat berupa alat bahkan pemanfaatan teknologi yang tidak hanya mengandung konten, tetapi lebih menekankan pada 
proses pembelajaran. Teknologi yang dimaksud mulai dari gambar sampai teknologi multimedia yang memanfaatkan banyak perangkat dalam pengoperasiannya. Mengacu pada pengetahuan teknologi konten dan bagaimana menggunakan teknologi untuk menyajikan dan mengajarkan materi pembelajaran, maka pemanfaatan media dalam pembelajaran tidak terlepas dari beberapa aspek, yakni: materi pembelajaran, proses pembelajaran dan siapa yang menjadi terget pembelajaran.

Peserta didik usia sekolah dasar berada pada rentang usia 7-12 tahun. Piaget mengatakan anak pada pada rentang usia ini berada pada tahap perkembangan kognitif operasional konkrit. Anak pada fase ini belajar melalui hal-hal konkrit yang mampu ditangkap oleh alat inderanya. Semakin banyak indera anak yang terlibat, maka hasil belajar akan semakin baik (Arsyad, 2009). Selain pelibatan indera, emosi memegang peranan penting dalam pencapaian hasil belajar (Frost, 1971). Pelibatan indera dan emosi dapat dijadikan pertimbangan dalam pemilihan media pembelajaran untuk memcapai hasil pembelajaran yang lebih baik. Emosi yang dimaksud salah satunya adalah rasa senang yang dimiliki oleh peserta didik.

Pemilihan media yang tepat diharapkan dapat memberikan stimulus yang akan meningkatkan rasa senang siswa untuk belajar. Komik merupakan media cetak yang didalamnya terdapat gambar-gambar menarik dan memiliki alur cerita yang lucu. Komik memiliki keunikan karena didalamnya terdapat gambar, panel-penel, balon-balon teks dan alur cerita yang digambarkan tidak berurutan sehingga menantang peserta didik untuk memiliki keleluasaan menyusun alur ceritanya. Komik secara bahasa diartikan sebagai bercanda atau bersuka cita (Sasongko,2005).

Karena mengandung humor, komik sangat diminati. Awal kemunculan komik dikenal sebagai sarana hiburan, komik identik dengan cerita lucu dan diperkuat dengan tampilan visual yang akan mengundang tawa. Selain mengandung cerita lucu, ternyata komik memiliki keunggulan lain, yakni ketika tampilan visual memperkuat gambaran bagi si pembaca, tidak memerlukan imajinasi liar seperti halnya ketika seseorang membaca naskah verbalistis. Pada fase selanjutnya, keberadaan komik mengalami perubahan, komin tidak selalu membahas hal yang lucu. Komik dirancang untuk memiliki topik serius termasuk merambah dunia Pendidikan. Komik dikembangkan sebagai media pembelajaran dalam bentuk bahan ajar dengan harapan dapat meningkatkan menyampaikan pesan pembelajaran dengan melibatkan indera dan emosi peserta didik.

Pendidikan merupakan kunci kemajuan, semakin baik kualitas Pendidikan suatu bangsa, maka akan semakin baik kualitas bangsa tersebut. Rahman (2009) menyatakan bahwa 
reformasi dan perubahan harus dimulai dari pendidikan. Segala aspek penunjang pembelajaran yang merupakan bagian dari proses pendidikan turut mengalami reformasi dan perubahan. Tersedianya media pembelajaran yang memiliki muatan Islami sebagai salah tantangannya. Menurut data EMIS Kementerian Agama, saat ini terdapat 1.709 Madrasah Ibtidaiyah Negeri di Indonesia. Media pembelajaran yang digunakan di madrasah tidak memiliki spesifikasi bernuansa Islam. Idealnya penguatan nilai-nilai Islam pada madrasah yang konsentrasi keIslamannya lebih tinggi.

$$
\text { Pemberlakuan Kurikulum }
$$

2013 juga mengharuskan madrasah menerapkan tematik dalam pembelajarannya. Ketersediaan media pembelajaran yang bernuansa Islami tidak tersedia. Salah satu media yang dapat dikembangkan adalah komik. Penelitian yang mengembangkan komik sebagai media telah banyak dilakukan, diantaranya yang dilakukan oleh Alaydrus (2019) yang mengembangkan Kolami sebagai media pembelajaran agama bagi anak jalanan, Pratama (2018) yang memanfaatkan Media Komik dalam pembelajaran Pendidikan Agama Islam, dan Febriyanti, dkk (2020) yang mengembangkan media komik berbasis Edutinment Secara Integratif di Sekolah. Penelitian yang mengembangkan media komiik temtik Islami masih sedikit ditemukan. Dalam artikel ini akan dibahas pengembangan media komik tematik Islami yang valid, praktis dan efektif. Melalui pengembangan media komik tematik Islami diharapkan dapat meningkatkan hasil belajar peserta didik.

\section{METODE PENELITIAN}

Penelitian ini dilakukan di Kecamatan Sunggal Kota Medan. Siswa dari MIS Islamiyah Sunggal dan SD Islam Qurrotu'ayyun diikutsertakan dalam penelitian ini. Siswa kelas IV MIS Islamiyah Sunggal dan SD Islam Qurrotu'ayyun menjadi sampel penelitian. Desain penelitian untuk penelitian ini adalah Research and Development (R\&D). Penelitian dan Pengembangan adalah proses penelitian yang melibatkan pembuatan produk dan mengevaluasi kemanjurannya. 2010 (Sugiyono). R\&D (Research and Development) adalah proses penelitian yang mencoba mengungkap, merumuskan, menyempurnakan, mengembangkan, membuat, dan menguji keefektifan produk, model, metode/strategi/metode, secara sistematis dan terencana. pelayanan, dan prosedur yang lebih baik, lebih maju, baru, lebih efektif, efisien, produktif, dan bermakna (Putra, 2011).

Dalam penelitian ini produk yang akan dikembangkan berupa Komik Tematik Islami yang valid, praktis dan efektif. Metode yang digunakan dalam penelitian ini adalah lembar validasi, angket dan tes hasil belajar. Lembar validasi digunakan untuk menguji tingkat kevalidan produk yang terdiri dari validitas konstruk dan isi. Angket digunakan 
Nurul Fadillah, Nirwana Anas, Rora Rizky Wandini : Pengembangan ...

untuk menguji kepraktisan produk yang diberikan kepada guru dan peserta didik. Tes hasil belajar digunakan untuk menguji keefektifan produk. Untuk menguji signifikasi produk menggunakan uji komparatif one sampel $t$ test dengan menggunakan bantuan SPSS Versi 22 dengan taraf signifikan 0,05.

\section{HASIL PENELITIAN DAN PEMBAHASAN}

Validasi Produk Komik Tematik Islami dilakukan untuk melihat dan mengevaluasi secara

runtun instrumen dan produk yang dikembangkan sehingga penggunaanya sesuai dengan tujuan yang hendak dicapai. Validasi produk dilakukan untuk melihat validitas, kepraktisan, dan efektivitas produk Komik Tematik Islami untuk meningkatkan hasil belajar siswa. Validasi produk Komik Tematik Islami meliputi validasi desain, validasi isi, validasi pembelajaran, dan validasi bahasa. Hasil validasi terhadap Komik Tematik Islami disajikan pada Tabel 1.

Tabel 1. Hasil validasi terhadap Komik Tematik Islami

\begin{tabular}{cll} 
No & \multicolumn{1}{c}{ Aspek } & \multicolumn{1}{c}{ Skor } \\
\hline 1 & Media & $88.33 \%$ \\
\hline 2 & Materi & $96,87 \%$ \\
\hline 3 & Bahasa & $95.83 \%$ \\
\hline 4 & Ahli pembelajaran & $95 \%$ \\
\hline & Jumlah & 376.03 \\
\hline & Rata-rata Skor & $94.01 \%$ \\
& Kriteria & Sangat layak \\
\hline
\end{tabular}

Dari hasil validasi ahli untuk produk Komik Tematik Islami menunjukkan rata-rata skor $94.01 \%$ sesuai dengan kriteria maka dapat dikategorikan "sangat layak". Kriteria sangat layak memiliki arti bahwa secara validitas bahwa produk Komik Tematik Islami dinyatakan layak untuk digunakan dari segi konstruk dan isi. Penelitian ini melibatkan guru dan peserta didik sebagai responden. Guru dan peserta didik diberikan Komik Tematik Islami yang telah dikembangkan. Guru dan peserta didik diminta untuk mengisi angket dan memberikan pendapat untuk memberi nilai kepraktisan produk yang telah dikembangkan.

Dari angket yang diisi oleh guru dan peserta didik diperoleh rata-rata kepraktisan Komik Tematik Islami sebesar $77.60 \%$ dengan kriteria "sangat praktis". Kriteria sangat praktis memiliki makna bahwa produk Komik Tematik Islami dinyatakan praktis untuk digunakan. Uji efektivitas produk dilakukan melalui hasil uji N-Gain. Diperoleh hasil belajar dengan nilai pretest 60.00 dan nilai postest 81.67. Setelah dilakukan uji N-Gain maka diperoleh nilai Gain ternormalisasi sebesar 0.54 
kategori sedang. Berdasarkan hasil uji efektivitas diperoleh peningkatan hasil belajar berada pada kategori sedang.

Produk Komik Tematik Islami divalidasi untuk mengetahui kemampuan penggunaan dan kualitas daya guna dalam rangka menciptakan inovasi media pembelajaran. Hasil validasi yang diperoleh dari ahli desain, ahli materi, ahli bahasa dan ahli pembelajaran secara keseluruhan memperoleh kategori "Sangat Layak" untuk digunakan. Ahli desain memberikan nilai validasi terhadap produk Komik Tematik Islami sebesar $88,33 \%$. Aspek yang dinilai ahli desain meliputi pewarnaan, desain, grafis, pemakaian kata atau bahasa, dan kelayakan penggunaan Komik Tematik Islami dalam pembelajaran. Desain Komik Tematik Islami menggunakan karikatur islami serta berlatarbelakang tempat yang dekat dengan siswa. Gambar juga dikaitkan dengan materi pembelajaran dari beberapa mata pelajaran. Produk Komik Tematik Islami menyajikan gambar yang dapat meningkatkan hasil belajar baik kognitif, afektif, maupun psikomotorik.

Hasil validasi yang diberikan ahli materi terhadap produk Komik Tematik Islami memperoleh hasil sebesar 96,87 \% dengan kategori "Sangat Layak". Penilaian ahli materi meliputi aspek penyajian, isi materi, dan umpan balik. Materi pembelajaran dalam Komik Tematik Islami ialah materi keberagaman yang ada disekitar, bunyi, gagasan pokok dan gagasan pendukung dengan mata pelajaran Ilmu Pengetahuan Sosial, Ilmu Pengetahuan Alam, dan Bahasa Indonesia. Ketiga materi pembelajaran tersebut disajikan dalam bentuk cerita bergambar yang nyata dan dekat dengan siswa, sehingga pembelajaran lebih kontekstual.

Hasil validasi produk Komik Tematik Islami yang diberikan ahli bahasa memperoleh hasil 95,83. Nilai tersebut diperoleh dari aspek lugas, komunikatif, dan kesesuaian kaidah bahasa. Kualitas produk Komik Tematik Islami termasuk dalam kategori "Sangat Layak". Bahasa yang terdapat dalam komik disesuaikan dengan usia siswa sehingga siswa memahami pesan dan informasi yang terdapat dalam komik. Ahli pembelajaran memberikan penilaian validasi terhadap Komik Tematik Islami sebesar $95 \%$ dengan kategori "Sangat Layak". Penilaian validasi pembelajaran meliputi penilaian penampilan dan efektivitas Komik Tematik Islami, penyajian materi Komik Tematik Islami, keterkaitan Komik Tematik Islami, dan keterlibatan peserta didik dalam menggunakan Komik Tematik Islami. Berdasarkan hasil yang diperoleh dari setiap validasi ahli, dapat disimpulkan kevalidan produk Komik Tematik Islami secara keseluruhan yaitu $94 \%$ dan mendapat kategori "Sangat Layak" digunakan sebagai media pembelajaran di Kelas IV MI/SD.

\section{Pembahasan}

Produk Komik Tematik Islami dinyatakan praktis melalui kuesioner yang dibagikan kepada responden 
yaitu siswa kelas IV sebanyak 21 responden. Tanggapan responden terkait produk Komik Tematik Islami memperoleh hasil penilaian yang dipersentasikan sebesar 77,60 \% dengan kategori "Sangat Praktis". Responden memberikan penilaian terhadap 16 indikator yang terdapat dalam kuesioner setelah responden menggunakan produk Komik Tematik Islami dalam pembelajaran. Hasil yang diperoleh melalui kuesioner tersebut mendapatkan respon yang baik dari guru dan siswa. Penggunaan Komik Tematik Islami mampu meningkatkan hasi belajar siswa karena Komik Tematik Islami memuat materi, gambar, dan informasi yang sesuai dengan tujuan pembelajaran.

Kepraktisan Komik Tematik Islami dapat dilihat dari penggunaan produk oleh siswa, guru, teman sejawat, dan pengguna lainnya yang tidak mengalami kesulitan saat menggunakan komik dalam pembelajaran. Komik Tematik Islami juga sesuai dengan kurikulum yang berlaku dikarenakan komik tersebut berbasis tematik yang mengintegrasikan beberapa mata pelajaran dalam satu tema. Produk Komik Tematik Islami dikatakan praktis jika siswa dengan mudah menggunakan produk tersebut sehingga meningkat hasil belajar siswa dari sebelum menggunakan komik hingga sesudah menggunakan komik. Efektivitas produk Komik Tematik Islami diuji menggunakan uji One-Sampel Statistics. Responden dalam uji ini berjumlah 21 responden.
Hasil uji One-Sampel Statistics menunjukkan adanya peningkatan sebelum dan sesudah penggunaan produk Komik Tematik Islami. Nilai yang diperoleh sebelum menggunakan Komik Tematik Islami sebesar 60,00 dengan standart deviasi 8,944 . Nilai yang diperoleh sesudah menggunakan Komik Tematik Islami sebesar 81,67 dengan standart deviasi 8,114 . Adapun selisih nilai rata-rata sebelum dan sesudah menggunakan Komik Tematik Islami yaitu 21,67.

Selisih nilai rata-rata diperoleh dengan mengurangkan hasil sesudah menggunakan Komik Tematik Islami dan sebelum menggunakan Komik Tematik Islami. Peningkatan nilai yang diperoleh siswa tetunya dari proses pembelajaran menggunakan komik untuk menyampaikan materi pembelajaran sehingga terjadi perubahan pada hasil belajar siswa. Komik Tematik Islami dikatakan efektif dalam pembelajaran karena mampu meningkatkan hasil belajar siswa. Komik Tematik Islami merupakan kumpulan gambar yang disusun membentuk jalinan cerita dikombinasikan dengan teks atau informasi visual yang berisi materi pembelajaran. Produk Komik Tematik Islami menjadi media pembelajaran untuk meningkatkan hasil belajar tematik siswa kelas IV. Produk Komik Tematik Islami memuat beberapa mata pelajaran seperti Ilmu Pengetahuan Sosial, Ilmu Pengetahuan Alam, dan Bahasa Indonesia yang terangkum dalam Tema 1 Subtema 1 Pembelajaran 1 dengan materi pelajaran yaitu Ragam 
budaya bangsaku, bunyi, gagasan pokok dan gagasan pendukung. Komik diberikan kepada siswa saat proses pembelajaran dimulai sebagai media pembelajaran disamping buku teks yang digunakan siswa.

Produk Komik Tematik Islami mengalami revisi yang disesuaikan dengan ahli yang memberikan penilaian, kritik, dan saran sehingga produk Komik Tematik Islami lebih baik dari sebelumnya. Produk Komik Tematik Islami diawali dengan judul "Ragam Budaya Bangsaku di Pekan Raya Sumatera Utara (PRSU). Selain judul, terdapat keterangan materi kelas IV Tema 1 Subtema 1 serta nama penulis. Tokoh didalam komik juga dihadirkan pada cover dengan tujuan memberikan pengenalan awal tokoh kepada siswa. Halaman setelah cover menjelaskan tentang masingmasing nama tokoh dan karakter tokoh dengan tujuan ketika siswa mengikuti alur cerita Komik Tematik Islami mampu mengambil sifat dan sikap yang baik dari tokoh dan meninggalkan sikap dan sifat yang buruk pada tokoh tersebut.

Gambar siswa di sekolah dan rumah menunjukkan sikap gotong royong dalam menyelesaikan tugas kelompok disekolah. Mereka menerapkan pembelajaran diskusi yang membuat siswa lebih aktif dan kritis. Gambar selanjutnya ketika mereka sudah tiba di Pekan Raya Sumatera Utara (PRSU) sikap tanggung jawab diperlihatkan pada halaman ini. Sosok ketua kelompok yang membagikan langsung tiket masuk dan menghimpun agar anggota kelompoknya tidak berpencar. Gambar sholat maghrib berjamaah menunjukkan sikap relegius yang ditonjolkan dalam komik ini. Pada halaman ini ragam budaya Kota Medan sudah diperlihatkan seperti Istana Maemon, kantor pos tempo dulu, dan kerajinan tangan khas Kota Medan. Ragam budaya yang pertama dikenalkan dalam komik ini ialah Kota Medan sebagai ibukota Provinsi Sumatera Utara.

Setelah berkunjung ke stand Kota Medan, ragam budaya dilanjutkan ke stand Toba Samosir. Toba Samosir merupakan ikon wisata yang terkenal di Indonesia karena danaunya sangat luas dan kisah legendaris yang terkenal. Halaman ini memperkenalkan berbagai ragam budaya Toba Samosir seperti rumah adat, alat musik tradisional, pakaian adat, dan beberapa patung yang dihormati dalam adat Toba Samosir. Ragam budaya selanjutnya berada di stand Karo dengan ikon wisata yang cukup terkenal yaitu pegunungan dan cuaca dinginya. Karo memiliki gunung berapi yang aktif sampai saat ini yaitu gunung Sinabung. Halaman ini menjelaskan ragam budaya karo seperti pakaian adat Karo, rumah adat Karo, dan hasil pertanian yang ada di daerah bercuaca dingin tersebut karena letak pertaniannya tepat dibawah kaki gunung.

Tapanuli Tengah menjadi ragam budaya setelah Karo yang mereka kunjungi. Halaman ini juga mulai memperkenalkan bunyi yang dihasilkan dari alat musik tradisional yang sedang dimainkan. Tidak hanya 
Nurul Fadillah, Nirwana Anas, Rora Rizky Wandini : Pengembangan ...

alat musik, pakaian adat, pelaminan pernikahan, kain tenun juga melengkapi ragam budaya Tapanuli Tengah. Saat yang bersamaan sebuah kesenian sedang dimainkan menambah wawasan para tokoh yang sedang berkunjung. Setelah Tapanuli Tengah yang memperkenalkan ragam budayanya, para tokoh menuju stand Tapanuli Selatan yang lebih banyak dikenal dengan Mandailing Natal. Stand ini dibuka dengan rumah adat yang menawan serta pakaian adat yang khas seperti topi bolang untuk pengantin wanita dan topi ampu untuk pengantin pria. Gendang sembilan yang menjadi ciri khas Tapanuli Selatan juga diperlihatkan dalam komik. Kerajinan tangan yang digunakan sebagai tempat sirih serta tikar lapis tempat duduk para Raja menambah daftar ragam budaya Tapanuli Selatan. Stand terakhir yang dikunjungi oleh para tokoh dalam komik ialah stand Langkat yang terkenal dengan suku Melayu. Langkat terkenal suku Melayu, makanan khasnya adalah Halua. Stand dibentuk bergaya masjid Azizi yang menjadi peradaban Melayu pada zamannya.

Gambar yang diletakkan dalam bingkai foto tidak menjadi alasan untuk tidak menambah wawasan budaya tentang Kabupaten Langkat. Selain Masjid Azizi, terdapat manisan, topi Melayu dan Pakaian adat Melayu dalam halaman ini. Tibalah pada halaman terakhir komik yang menceritakan berakhirnya pencarian para tokoh dalam komik di PRSU sehingga mereka pulang ke rumah masing-masing. Masingmasing tokoh mendapatkan tugas membuat karangan tentang informasi yang telah didapatkan di PRSU dan membuat gagasan pokok serta gagasan pendukung karangan tersebut.

\section{SIMPULAN}

Kesimpulan yang dapat
diambil berdasarkan temuan kajian
dan pembahasan penelitian ini, yaitu: 1) Komik Tematik Islami dinyatakan valid. Hasil validasi ahli yang meliputi ahli desain, ahli materi, ahli bahasa, dan ahli pembelajaran menunjukkan hal tersebut. Pada kategori Sangat Layak, Komik Tematik Islami mendapat skor 94,01 persen. Komik Tematik Islami dianggap bermanfaat. Informasi ini berasal dari kuesioner yang diisi oleh 21 siswa. Pada kategori "Sangat Praktis" Komik Tematik Islam memperoleh skor 77,60 persen. dan 3) Komik Tematik Islami bermanfaat dalam meningkatkan hasil belajar. Antara sebelum dan sesudah menggunakan Komik Tematik Islam, efektivitas Komik Tematik Islam meningkat. Ada perbedaan 21,67 persen antara sebelum dan sesudah menggunakan Komik Tematik Islami. Setelah menerapkan Komik Tematik Islam, nilai dinaikkan sebesar 21,67. Sebelum menggunakan Komik Tematik Islam nilai rata-ratanya adalah 60,00, dan setelah menggunakan Komik Tematik Islam, nilai rata-ratanya adalah 81,67. Komik Tematik Islami dapat 
dibangun bermanfaat dalam meningkatkan hasil belajar siswa.

\section{DAFTAR RUJUKAN}

Sasongko, Setiawan G. 2005. Kartun Sebagai Media Dakwah. Jakarta: Sisma Digi Media.

Nusa, Putra. 2011. Research \& Development. Jakarta: Rajawali Pers

Alaydrus, F. M. 2019. Komik Islami

(Kolami) Sebagai Media Pembelajaran Agama Bagi Anak Jalanan.Al-Hikmah:

Jurnal Kependidikan Dan Syariah, 6 (2), 51-56.

Rahman, F. 2009. Major Themes of the Qur'an. Chicago: University of Chicago Press.

Pratama, Y. A. 2018. Media Komik Dalam Pembelajaran Pendidikan Agama Islam Di Sdn 1 Sukabumi Bandar Lampung. Jurnal Mudarrisuna: Media Kajian Pendidikan Agama Islam, 8(2), 347-371. 